U.S DEPARTMENT OF THE INTERIOR

U.S. GEOLOGICAL SURVEY

\title{
Evaluation of the Effects of Development on Peak-Flow Hydrographs for Collyer Brook, Maine
}

Water-Resources Investigations Report 01-4156

In cooperation with the

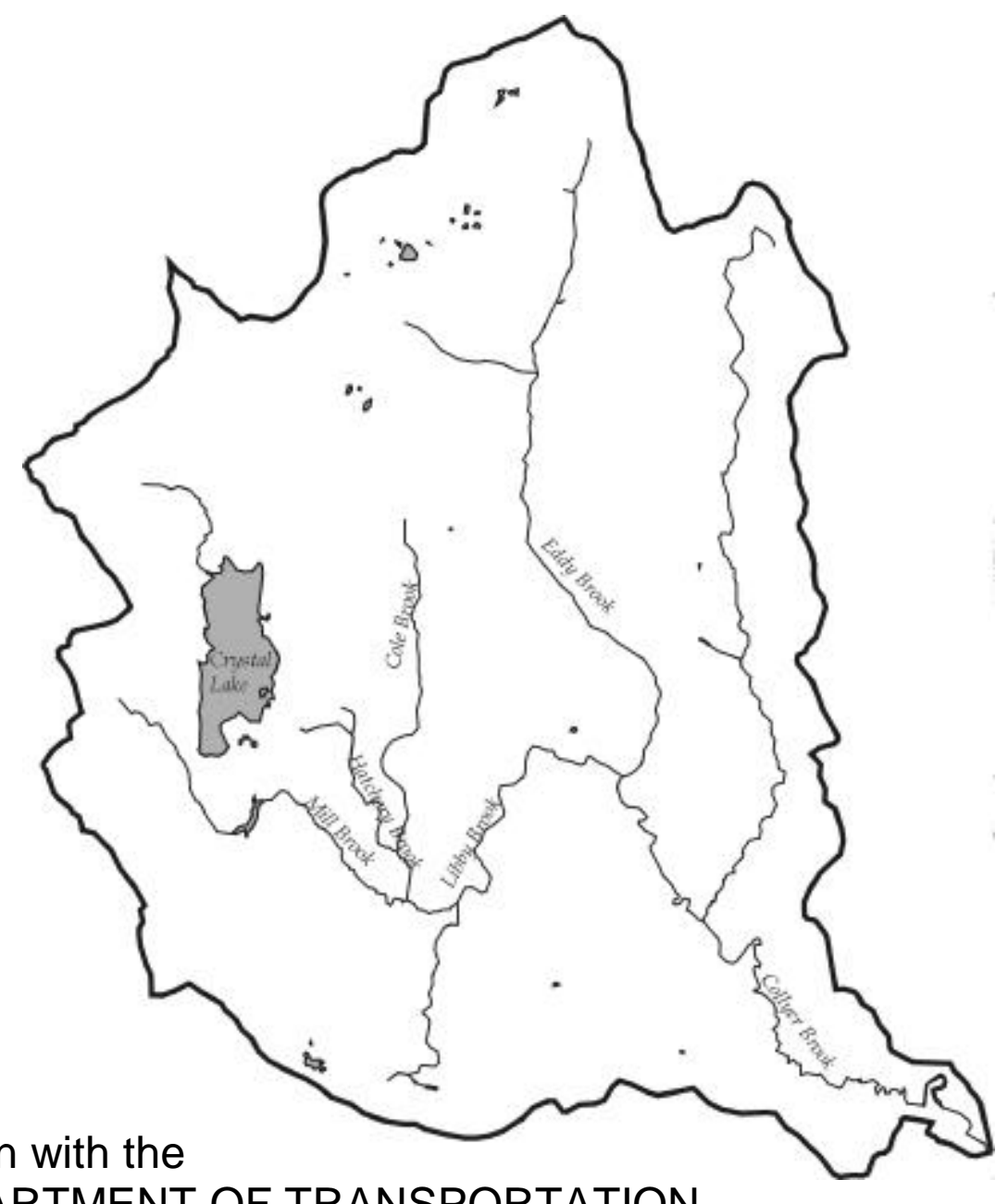

MAINE DEPARTMENT OF TRANSPORTATION

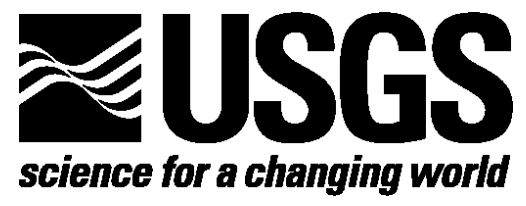




\title{
Evaluation of the Effects of Development on Peak-Flow Hydrographs for Collyer Brook, Maine
}

By Robert Dudley, Glenn Hodgkins, Alexander Mann, and John Chisholm

\author{
U.S. GEOLOGICAL SURVEY \\ Water-Resources Investigations Report 01-4156
}

In cooperation with the

MAINE DEPARTMENT OF TRANSPORTATION

Augusta, Maine 


\section{U.S. DEPARTMENT OF THE INTERIOR \\ GALE A. NORTON, Secretary}

U.S. GEOLOGICAL SURVEY

Charles G. Groat, Director

The use of firm, trade, and brand names in this report is for identification purposes

only and does not constitute endorsement by the U.S. Geological Survey.

For additional information write to:

Copies of this report can be purchased from:

District Chief

U.S. Geological Survey

26 Ganneston Drive

Augusta, ME 04330

http://me.water.usgs.gov
U.S. Geological Survey

Information Services

Box 25286

Federal Center

Denver, CO 80225 


\section{CONTENTS}

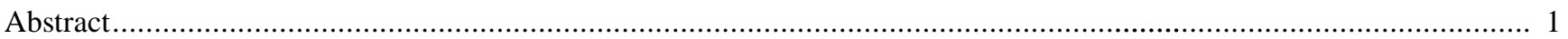

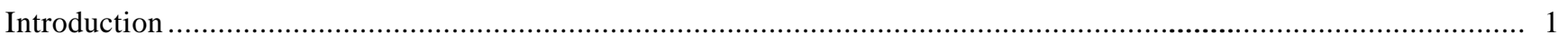

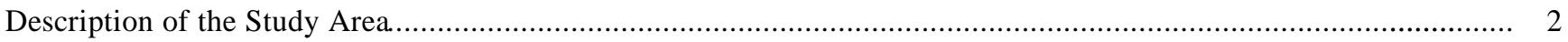

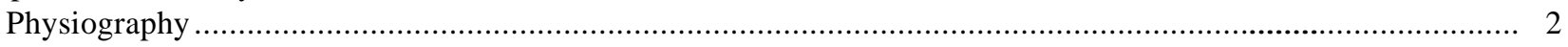

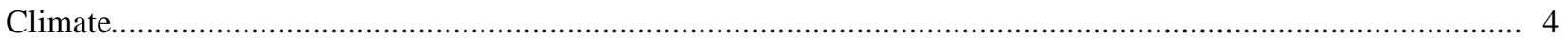

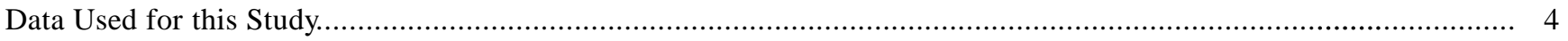

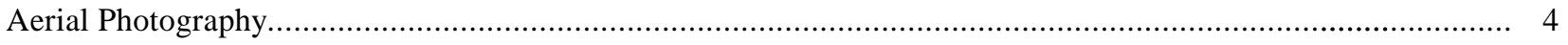

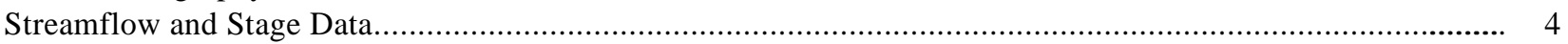

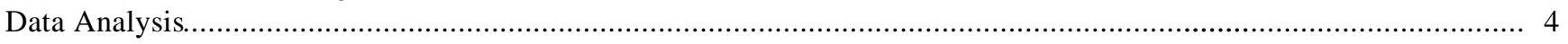

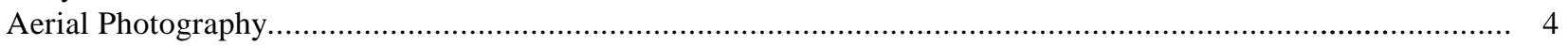

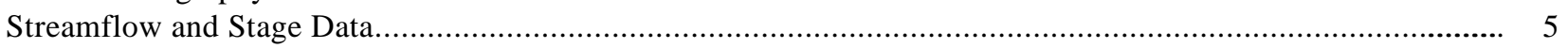

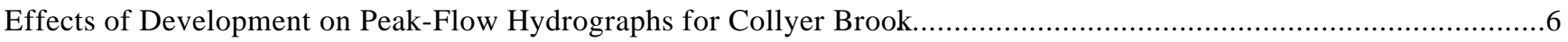

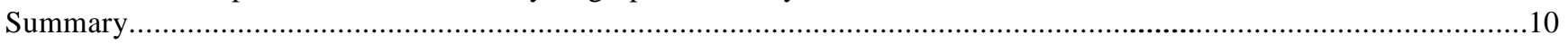

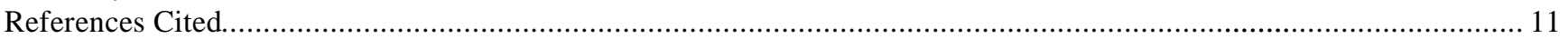

\section{FIGURES}

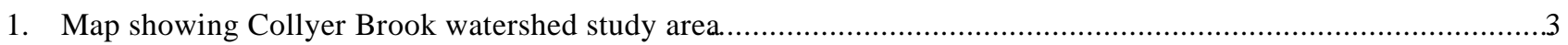

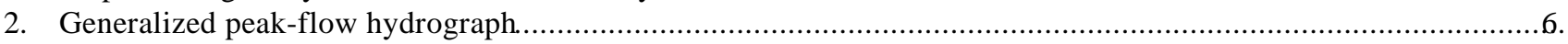

3. Relation of urban/rural 2-year peak-flow ratio (UQ2/RQ2) to basin development factor and impervious area.... 8

4. Relation of urban/rural 100-year peak-flow ratio (UQ100/RQ100) to basin development factor and impervious area..

\section{TABLES}

1. Data used to compute impervious area associated with buildings in the Collyer Brook watershed, 1964 and 1999

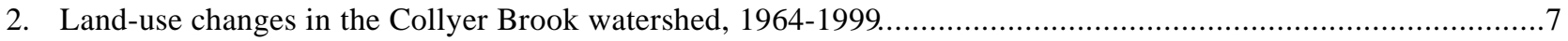

\section{PLATES}

1. Collyer Brook study area 1964 .

Appended

2. Collyer Brook study area 1999. Appended 
CONVERSION FACTORS AND VERTICAL DATUM

\begin{tabular}{rll}
\hline Multiply & By & To obtain \\
\hline cubic foot per second (ft'/s) & 0.02832 & cubic meter per second \\
foot (ft) & 0.3048 & meter \\
gallons per minute (gal/min) & 0.00223 & cubic feet per second \\
inch (in.) & 25.4 & millimeter \\
mile (mi) & 1.609 & kilometer \\
square mile $\left(\mathrm{mi}^{2}\right)$ & 2.59 & square kilometer \\
\hline
\end{tabular}

To convert temperature in degrees Fahrenheit $\left.{ }^{\rho} \mathrm{F}\right)$ to degrees Celcius $\left({ }^{\circ} \mathrm{C}\right)$, use the following equation:

$$
{ }^{\circ} \mathrm{C}=5 / 9 *\left({ }^{\circ} \mathrm{F}-32\right)
$$

Sea Level: In this report "sea level" refers to the National Geodetic Vertical Datum of 1929 (NGVD of 1929)—a geodetic datum derived from a general adjustment of the first-order level nets of both the United States and Canada, formerly called Sea Level Datum of 1929. 


\title{
Evaluation of the effects of development on peak- flow hydrographs for Collyer Brook, Maine
}

\author{
by Robert Dudley, Glenn Hodgkins, Alexander Mann, and John Chisholm
}

\section{ABSTRACT}

The development of former agricultural or forested lands creates more impervious areas and drainage improvements that can increase the volume of runoff and decrease infiltration and ground-water recharge in a watershed. Drainage improvements also can improve the conveyance of runoff, decreasing the time of rise to peak flow between the start of a rainfall event and the peak surface-water runoff, and likewise decreasing the duration of the peak-flow event. The watershed of Collyer Brook in southern Maine was studied to evaluate the effect of land-use changes on peakflow hydrographs because of the known development in the area during the past 35 years and the availability of aerial photos and streamflow data for this time period.

Although aerial photography indicates that suburban development has increased in the watershed between 1964 and 1999, the overall effect of suburbanization on rainfall-runoff processes in the watershed did not produce a statistically detectable change in the peak-flow hydrographs for Collyer Brook.

\section{INTRODUCTION}

The spread of development outside of urban centers into undeveloped or historically agricultural land, also called "sprawl," has been taking place throughout the United States for decades (Lee and others, 1999). Urban develop- ment increases runoff by creating additional impervious areas and drainage improvements. Impervious areas, which are created by paving streets and constructing parking lots and buildings, inhibits infiltration of precipitation into the ground, thereby increasing the total volume of runoff. Drainage improvements, which include straightening, lining, enlarging, deepening, and clearing channels and developing storm drains, curbs, and gutters, improve conveyance of runoff. Increased impervious areas and improved conveyance of runoff can decrease the time of rise to peak flow from the start of a rainfall event to the peak surface-water runoff and lead to higher peaks and shorter durations for peak-flow events (Bedient and Huber, 1988).

The effect of development on the timing and (or) magnitude of peak flows, in regard to the design of bridges and culverts, is of particular concern to the Maine Department of Transportation (DOT). Culverts and bridges are designed to convey a specific peak flow based on current and anticipated levels of development in the watershed. If the effect of development on peak flows is greater than anticipated, the design for a culvert or bridge may not be adequate for the design life of the structure. Effects of development on the magnitude and timing of peak flows have not been well studied, especially in Maine. In 1998, the Maine DOT and the U.S. Geological Survey (USGS) began a cooperative study to evaluate the effect of development on peak flows in the Collyer Brook watershed. Collyer Brook was chosen 
because of the known development in the area over the past 35 years and the availability of aerial photography and streamflow data for this time period.

The purpose of this report is to evaluate the effect of development on peak flows in Collyer Brook. The evaluation involved (1) quantifying the development that has taken place in the watershed by classifying land-use types and measuring changes in these classifications using aerial photos taken in November 11, 1960; April 30, 1964; and April 30, 1999 and (2) statistically comparing changes in peak-flow hydrographs recorded by a USGS streamflow-gaging station that was operated on Collyer Brook from September 1964 to August 1967 and from July 1998 to November 2000.

\section{DESCRIPTION OF THE STUDY AREA}

Collyer Brook is in southern Maine, about 20 mi north of Portland (fig. 1); it drains a 19.8$\mathrm{mi}^{2}$ basin at its confluence with the Royal River (Cowing and McNelly, 1978). The study area on Collyer Brook is a 13.3- $\mathrm{mi}^{2}$ subbasin gaged by the USGS (station 01059800, Collyer Brook near Gray, Maine). The USGS gaging station is $3.4 \mathrm{mi}$ upstream from the mouth of Collyer Brook (fig.

1) (Nielsen and others, 2000).

The gaged subbasin of Collyer Brook is in the towns of Gray and New Gloucester, Cumberland County, Maine. During the past 29 years, Gray and New Gloucester have had population increases of 145 and 57 percent with 1999 populations of 7,200 and 4,400, respectively (Maine Register, 2000). Based on the average population density of the two towns, the population in the gaged Collyer Brook Subbasin approximately doubled. During the same three decades, the population of nearby Portland remained relatively unchanged with an overall 1.7 percent decrease to a 1999 population of 64,000 (Maine Register, 2000). These population data suggest that growth in population in the greater Portland area was largely through suburbanization. Development in
Gray and New Gloucester is predominantly residential -- 94 and 76 percent, respectively, of the total developed land in each town. The developed land classifications are based upon town plans and available land-use maps (U.S. Department of Agriculture, 1995).

\section{Physiography}

The study area has predominantly steep ridges along its boundaries and generally flat topography in the center (fig. 1). Crystal Lake, wetlands, springs, and kettle holes occupy the flat, central area of the watershed. Collyer Brook is the confluence of two smaller brooks: Eddy Brook and Libby Brook. Eddy Brook drains the wetlands in the northern half of the study area, whereas Libby Brook drains three smaller streams in the southern half: Cole, Mill, and Hatchery Brooks. Cole and Mill Brooks drain wetlands and ridges, and Hatchery Brook originates as springs near Crystal Lake. Crystal Lake is drained by the springs that feed Hatchery Brook and an outlet at the southern end of the lake into Mill Brook.

Land-surface altitudes range from $180 \mathrm{ft}$ above sea level at the USGS gage on Collyer Brook to $554 \mathrm{ft}$ above sea level on the ridgetop at the western drainage divide.

The flat, north-central part of the watershed contains subsurface materials predominantly composed of sand and gravel and coarse sand of variable thicknesses ranging from about 50 to 300 $\mathrm{ft}$. This flat sand-and-gravel region is an aquifer with moderate to good (generally greater than 10 $\mathrm{gal} / \mathrm{min}$ ) potential ground-water yields with a small area with good to excellent (100 gal $/ \mathrm{min})$ potential ground-water yields about $1,500 \mathrm{ft}$ east of Crystal Lake. This sand and gravel aquifer surrounds Crystal Lake on all sides except on the lake's western perimeter where it abuts the steep valley wall (Neil, 1999).

The hummocky hills and ridges south of Crystal Lake were formed at the marine shoreline and glacial ice margins during glacial retreat from this region. The marine ice-contact deposits left behind in this area include sorted and stratified 


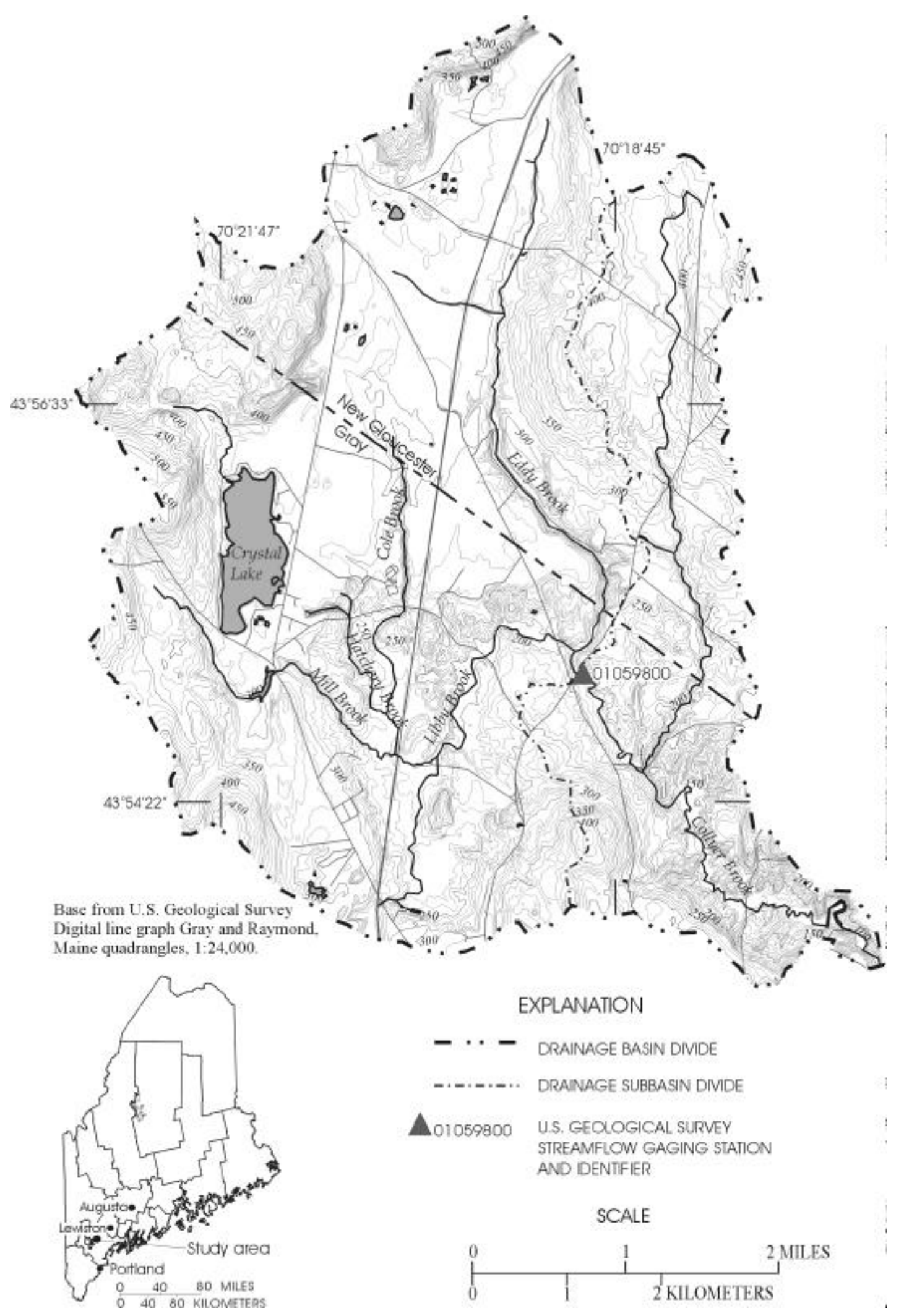

Figure 1. Collyer Brook watershed study area, southern Maine. 
sand and gravel interbedded and overlain by laminated silts, clays, and tills. The surrounding valley walls of the watershed are bedrock ridges overlain by relatively thin (about $10 \mathrm{ft}$ ) layers of sand, gravel, and till (Weddle, 1997; 1999).

\section{Climate}

The temperate climate in the Collyer Brook watershed is typified by mild summers and cold winters. Records from a National Weather Service (NWS) station in Lewiston, $14 \mathrm{mi}$ to the northeast, indicate an average annual temperature of $46^{\circ} \mathrm{F}$ with mean monthly temperatures ranging from $20^{\circ} \mathrm{F}$ in January to $71^{\circ} \mathrm{F}$ in July (U.S. Department of Commerce, National Oceanic and Atmospheric Administration, 1999). The average annual precipitation at the Lewiston station is 45.8 in and is fairly evenly distributed throughout the year (U.S. Department of Commerce, National Oceanic and Atmospheric Administration, 1992).

\section{DATA USED FOR THIS STUDY}

\section{Aerial Photography}

Stereoscopic 9-in. square panchromatic aerial-photo prints with a nominal scale of 1:9,600 were used to quantify changes in land use from the 1960's to the 1990's. Panchromatic aerial photos render electromagnetic radiation from the ultraviolet through the visible spectrum in tones of gray to produce black-and-white photographs. The nominal scale of each photographic set was verified using the corresponding USGS 7.5-minute quadrangles for Gray (published 1980) and Raymond (published 1981) as scale references. The aerial photographs were taken November 11, 1960, April 30, 1964, and April 30, 1999. The 1960 and 1964 photographs were combined to provide the historical 1964 land features and development. The 1999 photograph provided the modern land features and development.

\section{Streamflow and Stage Data}

Hydrologic data from the USGS gage on Collyer Brook were used to statistically compare changes in peak-flow hydrographs between historical (1964-67) and current (1998-2000) time periods. The Collyer Brook gaging station was installed September 1964 and operated continuously until it was discontinued in September 1982. Gage data from September 1964 to August 1967 were used to represent the historical hydrologic conditions. The Collyer Brook gaging station was re-instrumented in July 1998 to collect 2 additional years of data to represent current hydrologic conditions. The gage was discontinued in November 2000.

The mean annual flow at the Collyer Brook gaging station for water years ${ }^{1}$ 1964-2000 is $27.5 \mathrm{ft}^{3} / \mathrm{s}$. The gaging station recorded a maximum daily mean flow of $600 \mathrm{f} \mathrm{f} / \mathrm{s}$ on March 13, 1977 , and a minimum daily mean flow of $6.4 \mathrm{ft} / \mathrm{s}$ on January 29, 1966. The highest instantaneous flow recorded at the station was $1,220 \mathrm{ft}^{3} / \mathrm{s}$ on December 27, 1969 (Nielsen and others, 2000).

\section{DATA ANALYSIS}

\section{Aerial Photography}

All land features were delineated from the stereoscopic panchromatic aerial photographs using an Abrams stereoscope with two- to fourpower magnification and a computer-aided drafting (CAD) system. The land features digitized into the CAD system included wetlands, ponds, stream channels, roads, watershed boundaries, gravel pits, agricultural land, and forested land. The scale of all delineated land features were verified using USGS 7.5-minute topographic maps of the study area. Questionable delineations, such as

\footnotetext{
${ }^{1}$ The term "Water Year" denotes the 12-month period from October 1 through September 30 and is designated by the calendar year from which it ends and which includes 9 of the 12 months. Thus, the year ending September 30, 1999 is called "water year 1999."
} 
features in areas of low topographic relief or features obscured by shadow because of the time of day of the photography, were field checked.

Five major land-use categories were delineated for comparison between time periods: openwater and wetlands, forest, fields and other agricultural land, gravel, and impervious area. Fields and other agricultural land include blueberry barrens, brushy fields, hayfields, cultivated fields and row crops, and lawn area. The gravel category includes all gravel roads and gravel shoulders on paved highways in the study area. Gravel pits were not counted in the gravel category because they are closed basins and are not included as part of the total watershed area. Impervious land types include roofs, paved parking lots, highways, and paved driveways.

The impermeable area associated with buildings (roofs and parking lot/driveway pavement) was computed by counting all of the various building-types in the aerial photos and multiplying the totals by representative impervious areas as given in table 1 . The impermeable area of paved roads was computed by classifying all roads in the study area by type: interstate, State, and municipal. The linear miles of each paved roadway type (interstate, State, and municipal) were multiplied by their nominal pavement design width to obtain an area. For example, the total length of the Maine Turnpike in the study area (interstate classification) was multiplied by a width of $72 \mathrm{ft}$; State and municipal paved highways were multiplied by a pavement width of 22 $\mathrm{ft}$.

\section{Streamflow and Stage Data}

Peak-flow hydrographs for the historical and current time periods were used to analyze the effect of development on peak-flow events between time periods. Only peak-flow hydrographs from well-defined rainfall events for which the peak could be clearly identified were included in the study. Furthermore, the rainfallrunoff events had to be separated by enough time to allow for adequate recession of the hydrograph
Table 1. Data used to compute impervious area associated with buildings in the Collyer Brook watershed, southern Maine, 1964 and 1999 [na, not applicable]

\begin{tabular}{|c|c|c|c|}
\hline \multirow{2}{*}{ Building types } & \multicolumn{2}{|c|}{ Number of buildings } & \multirow{2}{*}{$\begin{array}{l}\text { Impervious } \\
\text { area per } \\
\text { building in } \\
\text { square feet }\end{array}$} \\
\hline & 1964 & 1999 & \\
\hline Houses & 165 & 745 & 1,600 \\
\hline Driveways & na & na & 800 \\
\hline Garages & 83 & 298 & 1,100 \\
\hline Attached farmhouses & 26 & 31 & 7,000 \\
\hline Barns & 54 & 28 & 3,600 \\
\hline Camps/trailers & 119 & 206 & 600 \\
\hline Industrial & 4 & 52 & 8,000 \\
\hline Parking lots & na & na & 80,000 \\
\hline
\end{tabular}

to meet the needs for analysis described below. Hydrographs with unexplained patterns were not used. In an effort to exclude ice-affected data or data affected by impervious frozen ground, peaks in any year between December 1 to March 31 were not used. Hydrographs from August 22, 1965, to September 30, 1965, also were not used because of unknown backwater effects from rocks on the control near the gaging station.

From the available historical and current peak-flow hydrographs that suited the above criteria, three sets of data were developed. The first data set was populated only with the magnitudes of the peak flows $\left(Q_{p}\right.$, fig. 2) for each peak-flow hydrograph.

The second data set was populated with the durations of parts of the recessions of the peak-flow hydrographs. Specifically, the data for this second data set was the time, in hours, for the flow to drop from $40 \mathrm{ft}^{3} / \mathrm{s}$ to $30 \mathrm{ft}^{3} / \mathrm{s}$ for each peak equal to or exceeding $40 \mathrm{ft}^{3} / \mathrm{s}$. These data were chosen because they are an indicator of the shape of the peak-flow hydrograph. The $40-$ to $30-\mathrm{ft}^{3} / \mathrm{s}$ range was chosen as the result of an iterative process that was intended to maximize both the recession range and the number of hydrograph recessions that contained the desired recession 


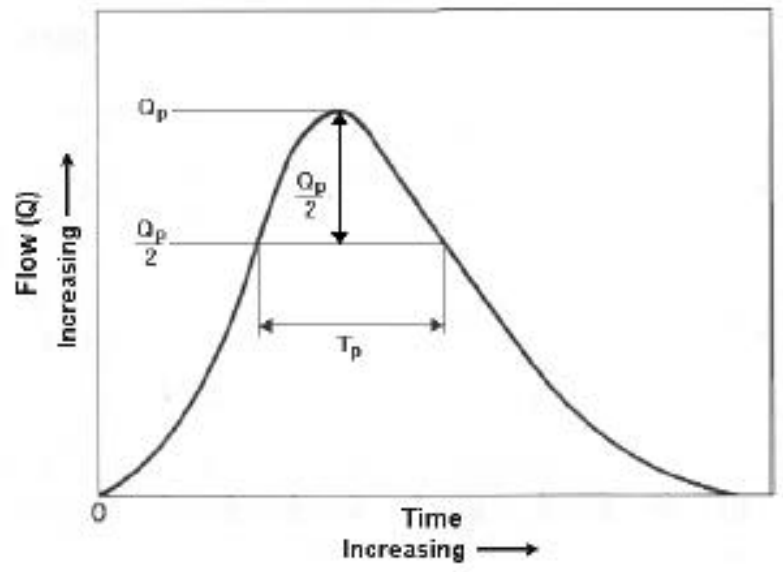

Figure 2. Generalized peak-flow hydrograph showing the peak flow $\left(Q_{p}\right)$, one-half of the peak flow $\left(Q_{p} / 2\right)$, and the duration of peak flow event $\left(T_{p}\right)$.

range for both time periods. A large recession range would provide greater power to the timeduration variable but would limit the number of cases for which the recession range occurred. A small range would have diminished power, but would yield a great number of peak-flow hydrographs for which the recession range is present. The 40 to $30-\mathrm{ft}^{3} / \mathrm{s}$ range provided the best balance between maximization of the recession range and number of events in which it occurred.

The third data set was populated with a derived flow statistic in which the difference between the peak flow and one-half of the peak flow $\left(\mathrm{Q}_{\mathrm{p}}-\mathrm{Q}_{\mathrm{p}} / 2\right)$ was divided by the duration of the peak-flow event ( $\mathrm{T}_{\mathrm{p}}$, fig. 2). This flow statistic was derived as an indicator of the shape of the peak-flow hydrograph. The duration, $\mathrm{T}_{\mathrm{p}}$, was defined as the time, in hours, from when the flow was equal to one-half of the peak flow on the rising limb of the hydrograph to the time when the flow was equal to one-half of the peak flow on the recession. The derived flow statistic was computed by the formula $\left(\mathrm{Q}_{\mathrm{p}} / 2\right) / \mathrm{T} \mathrm{p}$. For example, for a peak-flow event cresting at $38 \mathrm{ft}^{3} / \mathrm{s}, \mathrm{T}_{\mathrm{p}}$ would be the difference (in hours) between the times at which $19 \mathrm{ft}^{3} / \mathrm{s}$ occur on each side of the peak. For this example, assume $T_{p}$ is 17.0 hours. The derived flow statistic for this example is $19 / 17=$ $1.1 \mathrm{ft}^{3} /(\mathrm{s} \cdot \mathrm{hr})$.
Each of the three peak-flow data sets was subdivided into historical and current time periods and compared to statistically determine whether any changes in peak flow hydrographs had occurred over time. Each of the comparisons was evaluated using the Wilcoxon rank-sum test, a non-parametric alternative to the two-sample ttest. The rank-sum test is a widely used method to compare two independent groups of data. Being non-parametric, in its most general form, it requires no assumptions as to how the data are distributed. This form of the rank-sum test determines whether one group of data tends to produce different values (higher or lower) than another group (Helsel and Hirsch, 1992).

The null hypothesis for the rank-sum test states that the two groups of data in question (historical and current time periods) are the same. This null hypothesis is assumed to be true until proven otherwise. By statistically disproving the null hypothesis, the investigator would demonstrate that the two data sets are different from one another.

\section{EFFECTS OF DEVELOPMENT ON PEAK- FLOW HYDROGRAPHS FOR COLLYER BROOK}

Land-use types for each time period are compared in table 2. A 161-percent increase in impervious area from 1964 to 1999 in the watershed is accompanied by a decrease of fields and other agricultural land uses (22.4 percent decrease). Even with this increase in the number of buildings (triple that of 1964) and roads (37.6 mi of roads in 1964 compared to $45.8 \mathrm{mi}$ in 1999), the total impervious area present in 1999 is still a very small part of the entire watershed -- 3.5 percent of the total drainage area. The overall drainage area decreased 0.9 percent because of the expansion of the closed-basin gravel pits.

Major land-use types in the Collyer Brook watershed for 1964 and 1999 are illustrated on plates 1 and 2 . Although the open water and wetlands have remained unchanged, a clear increase 
Table 2. Land-use changes in the Collyer Brook watershed, southern Maine, 1964-1999

\begin{tabular}{|c|c|c|c|c|c|}
\hline \multirow{2}{*}{ Land-use type } & \multicolumn{2}{|c|}{1964} & \multicolumn{2}{|r|}{1999} & \multirow{2}{*}{$\begin{array}{c}\text { Percent } \\
\text { change in } \\
\text { area }\end{array}$} \\
\hline & $\begin{array}{c}\text { Area } \\
\text { (acres) }\end{array}$ & $\begin{array}{l}\text { Percent of total } \\
\text { watershed area }\end{array}$ & $\begin{array}{c}\text { Area } \\
\text { (acres) }\end{array}$ & $\begin{array}{l}\text { Percent of total } \\
\text { watershed area }\end{array}$ & \\
\hline Impervious & 112 & 1.3 & 293 & 3.5 & 161 \\
\hline Gravel & 67.8 & .8 & 71.5 & .8 & 5.4 \\
\hline Fields and other agricultural land & 1,080 & 12.6 & 838 & 9.9 & -22.4 \\
\hline Forest & 6,930 & 81.1 & 6,910 & 81.6 & -.3 \\
\hline Open water and wetlands & 359 & 4.2 & 359 & 4.2 & 0 \\
\hline Total watershed area & 8,550 & & 8,470 & & -.9 \\
\hline
\end{tabular}

in roads and paved surfaces has taken place. Expansion of the closed-basin gravel pit on Bennett Road and loss of fields to development and forest growth also are discernable.

Twenty peak flows were identified from 1964 to 1967 ranging from $28 \mathrm{ft}^{3} / \mathrm{s}$ to $605 \mathrm{ft}^{3} / \mathrm{s}$ with a median peak flow of $56 \mathrm{ft}^{3} / \mathrm{s}$. Nineteen peak flows were identified from 1998 to 2000 ranging from $29 \mathrm{ft}^{3} / \mathrm{s}$ to $792 \mathrm{ft}^{3} / \mathrm{s}$ with a median of $74 \mathrm{ft}^{3} / \mathrm{s}$. For statistical tests, significance levels of 0.01 to 0.1 typically are used as criteria to determine statistical significance of a test result. The result of the rank-sum test comparing the magnitude of peak-flow events between time periods $(\mathrm{p}=0.261)$ failed to reject the null hypothesis at a reasonable significance level (0.1). By not rejecting the null hypothesis, the test failed to demonstrate that the two populations are statistically different from one another.

The durations of peak-flow recessions from 1964 to 1967 ranged from $3.8 \mathrm{hr}$ to $24.9 \mathrm{hr}$ with a median of $8.2 \mathrm{hr}$. The durations of peakflow recessions from 1998 to 2000 ranged from $3.5 \mathrm{hr}$ to $34.5 \mathrm{hr}$ with a median of $8.2 \mathrm{hr}$. As with the comparison of peak flows, results of the comparison of durations of peak-flow recessions $(\mathrm{p}=$ 0.490 ) also failed to reject the null hypothesis at a reasonable significance level (0.1).

The derived flow statistics for peak-flow events from 1964 to 1967 ranged from $0.34 \mathrm{ft}^{3} /$ $(\mathrm{s} \cdot \mathrm{hr})$ to $23.3 \mathrm{ft}^{3} /(\mathrm{s} \cdot \mathrm{hr})$ with a median of $0.89 \mathrm{ft}^{3} /$ $(\mathrm{s} \cdot \mathrm{hr})$. The derived flow statistics for peak-flow events from 1998 to 2000 ranged from $0.40 \mathrm{ft}^{3} /$ $(\mathrm{s} \cdot \mathrm{hr})$ to $29.9 \mathrm{ft}^{3} /(\mathrm{s} \cdot \mathrm{hr})$ with a median of $1.61 \mathrm{ft}^{3} /$ $(\mathrm{s} \cdot \mathrm{hr})$. Results of the comparison of the derived flow statistics for peak-flow events $(\mathrm{p}=0.173)$ failed to reject the null hypothesis at a reasonable significance level (0.1).

The above comparisons of peak-flow hydrographs between time periods showed no change in the peak magnitudes, durations of recessions, or hydrograph shapes for peak-flow events in the Collyer Brook watershed. Although development has increased in the watershed from 1964 to 1999 (plates 1 and 2), the overall effect of development on rainfall-runoff processes in the watershed did not cause a statistically detectable change in the peak-flow hydrographs.

Sauer and others (1983) conducted a nationwide study of flood magnitude and frequency in urban drainage basins. They developed regression equations for estimating peak flows for ungaged, urban drainage basins. One set of regression equations calculates peak flow for a specific recurrence interval, $n$, based on seven explanatory variables: drainage area (A), main channel slope (SL), 2-hour, 2-year occurrence rainfall $\left(\mathrm{R}_{2}\right)$, percent of drainage basin that is wetland (ST), peak flow for an equivalent rural drainage basin and recurrence interval $n\left(\mathrm{RQ}_{\mathrm{H}}\right)$, percent 
impervious area (IA), and basin development factor (BDF). The BDF is an index (integer scale 0 to 12) of the prevalence of conveyance improvements including storm sewers, channel modifications (straightening, enlarging), impervious channel linings, and curb-and-gutter streets. A value of zero for BDF indicates that the above drainage improvements are not prevalent, but it does not necessarily mean that the basin is nonurbanized. A value of 12 indicates full development of the drainage aspects throughout the basin.

In the case of the Collyer Brook watershed, $A, S L, R_{2}, S T$, and $R_{n}$ have remained relatively constant over time; therefore, any changes in peak flow because of urbanization would depend solely upon increases in BDF and impervious area (IA). The sensitivity of urban/rural peak-flow ratios for the 2-year and 100-year peak flows to BDF and impervious area (UQ is the urban peak flow; RQ is the rural peak flow) is illustrated in figures 3 and 4 . In each figure, the zone labeled as "bulk of data within these limits" illustrates the location of the majority of the data used by Sauer and others (1983) to derive the equations. The regression equations used to produce the urban-to-rural contours in figures 3 and 4 have an average standard error of estimate of about 50 percent (Sauer and others, 1983).

The estimates of higher frequency (2-year) $\mathrm{UQ} / \mathrm{RQ}$ ratios are more sensitive to IA than low frequency (100-year) UQ/RQ ratios for relatively low levels of urbanization (figs. 3 and 4). Most of the peak flows examined for the Collyer Brook study are more frequent than the 2-year flow. The 2-year urban/rural peak-flow contours illustrated in figure 3 show that a BDF of zero and the pres-

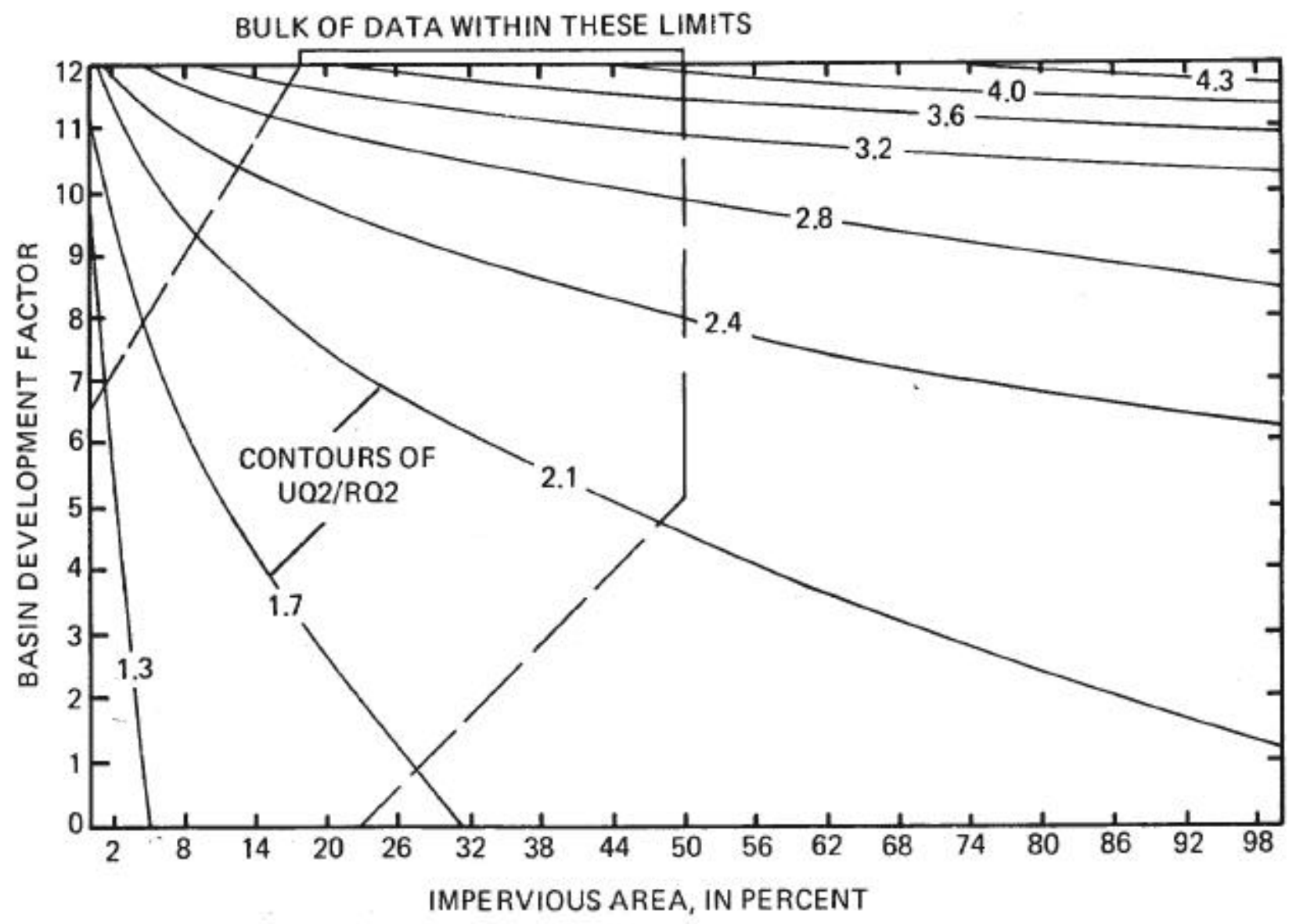

Figure 3. Relation of urban/rural 2-year peak-flow ratio (UQ2/RQ2; UQ, urban peak flow; RQ, rural peak flow) to basin development factor and impervious area (from Sauer and others, 1983, fig. 15). 


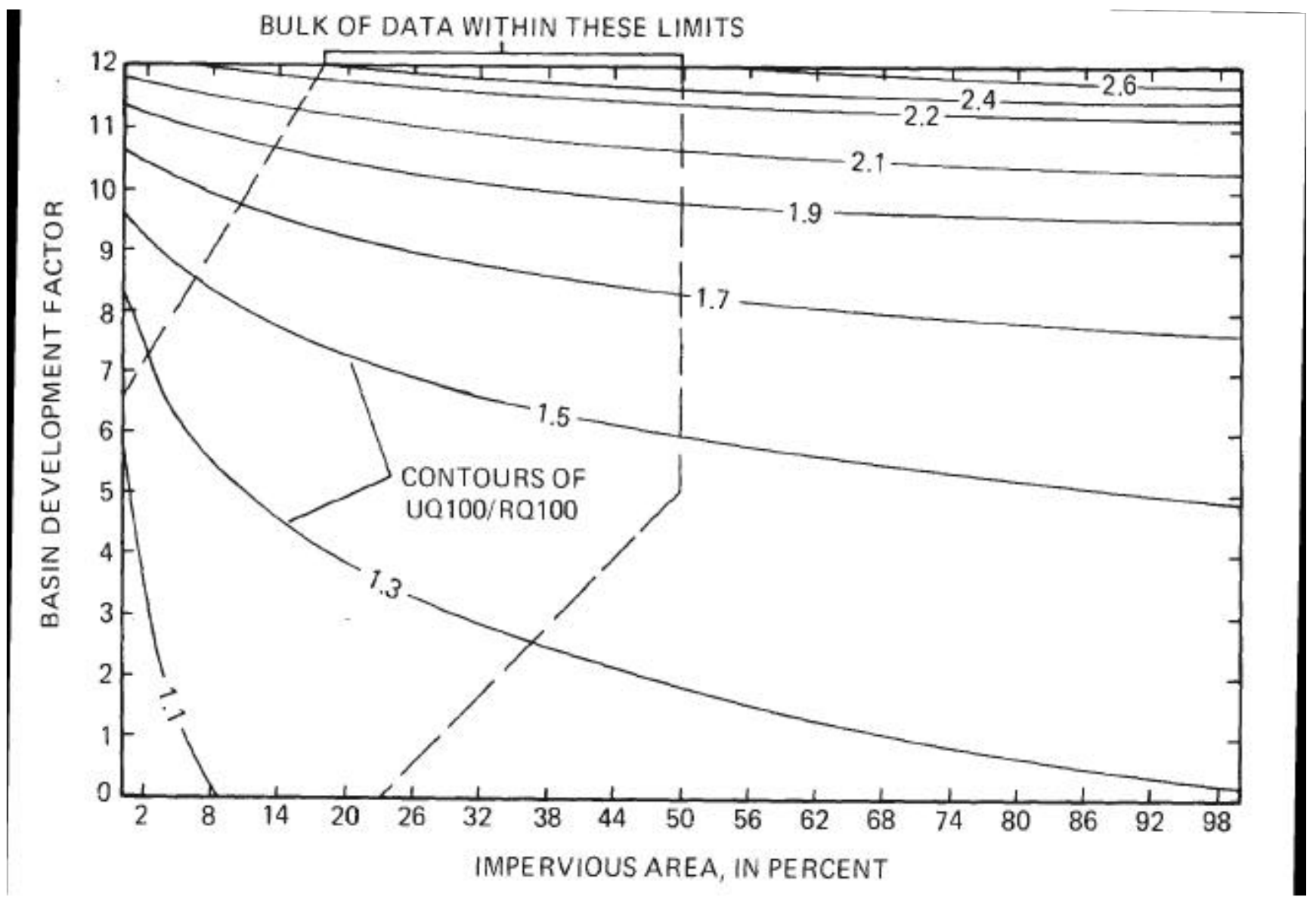

Figure 4. Relation of urban/rural 100-year peak-flow ratio (UQ100/RQ100; UQ, urban peak flow; RQ, rural peak flow) to basin development factor and impervious area (from Sauer and others, 1983, fig. 17).

ence of 5-percent impervious area would, on average, produce a 30-percent increase in flows in an urban watershed compared to its rural equivalent. For the same parameter values, the 100-year urban/rural peak flow contours illustrated in figure 4 show that, on average, the change would be less than 10 percent. With the BDF held constant at zero, the impervious area could be increased to more than 20 percent and the change would remain below 30 percent. High-frequency peak flows are more sensitive to changes in impervious area than low-frequency peak flows for relatively low levels of urbanization (figs. 3 and 4). This sensitivity may be because the saturated soils during lower frequency floods more closely approximate impervious areas.

Estimates of neither high-frequency peak flows nor low-frequency peak flows are affected greatly by increases in the BDF at relatively low levels of urbanization (figs. 3 and 4). The near vertical nature of the $1.3 \mathrm{UQ}_{2} / \mathrm{RQ}_{2}$ contour in figure 3 indicates that the $\mathrm{UQ}_{2} / \mathrm{RQ}_{2}$ ratio is relatively insensitive to changes in the BDF. For the 100-year peak flow, a BDF below 3 with 5-percent impervious area would have an urban-torural ratio near 1.1. At higher levels of impervious area, however, the urban-to-rural peak-flow ratios become more sensitive to increases in BDF for the 100 -year peak flow.

Field reconnaissance in 2001 found that the BDF for the present Collyer Brook watershed is zero. The impervious area of the watershed more than doubled to 3.5 percent from 1964 to 1999 (table 2). It is important to note that an impervious area of less than 3 percent is outside of the range of data used by Sauer and others 
(1983) to develop their urban peak-flow regression equations. Using the parameter values of BDF equal to zero and an IA of 3.5 percent in the equation used to produce figure 4 yields a value of 1.08, indicating less than a 10-percent increase in the 100-year peak flow for the basin. Using the same parameter values in the equation used to produce figure 3 yields a value of 1.21 , or a 21 percent increase in the higher frequency 2-year peak flow. Given the standard error of these equations (about 50 percent), however, it is plausible that the estimated 2-year and 100-year peak flows did not increase or that the change may not be detectable.

High-frequency peak flows are sensitive to impervious area (particularly in the less than 10-percent range), so future increases in impervious area may begin to have a discernable effect on peak flows (fig. 3). If the impervious area of the watershed were to double again during the next 30 years to 7 percent, for example, the $\mathrm{UQ}_{2} / \mathrm{RQ}_{2}$ urban/rural peak flow equation would yield a 34percent increase in 2-year peak flow magnitudes, assuming no increase in BDF, compared to its rural equivalent. If drainage improvements were to increase in the basin as well, the effect presumably would become more pronounced.

\section{SUMMARY}

The effect of development on peak flow hydrographs, in regard to the design of bridges and culverts, is a concern in Maine. In 1998, the Maine DOT and the USGS began a study to evaluate the effect of land-use changes on peak flows in the Collyer Brook watershed. Collyer Brook, in southern Maine, is about $20 \mathrm{mi}$ north of Portland and drains a $19.8-\mathrm{mi}^{2}$ basin at its confluence with the Royal River. This report presents an evaluation of the effects of development on peak flows in Collyer Brook.

The evaluation involved (1) quantifying the development in the watershed by classifying land-use types and measuring changes in these classifications using aerial photos taken in
November 11, 1960; April 30, 1964; and April 30, 1999 and (2) statistically comparing changes in peak-flow hydrographs recorded by a USGS streamflow-gaging station from September 1964 to August 1967 and from July 1998 to November 2000. Three sets of data were developed from the streamflow and stage data: magnitudes of the peak flows, durations of parts of the recessions of the peak-flow hydrographs, and derived flow statistics in which the difference between the peak flow and one-half of the peak flow was divided by the duration of the peak-flow event. These three sets of data were subdivided into historical (196467) and current (1998-2000) time periods, and statistically compared using the Wilcoxon ranksum test to determine whether any statistically significant changes have occurred over time.

During the past 29 years, the population in the gaged Collyer Brook Subbasin approximately doubled. A 161-percent increase in impervious area in the watershed is accompanied by a decrease of fields and other agricultural land uses. Despite the large percentage growth in population and development, the total impervious area present in 1999 still is a very small part of the entire watershed -- 3.5 percent of the total drainage area. The comparisons of peak-flow hydrographs between time periods showed no change in the peak magnitudes, durations of recessions, or hydrograph shapes for peak-flow events in the Collyer Brook watershed. Although development has increased in the watershed from 1964 to 1999 , the overall effect of development did not cause a statistically detectable change in the peak-flow hydrographs.

On the basis of regression equations developed by Sauer and others, estimates of higher frequency peak-flows (2-year) are more sensitive to changes in impervious area than low frequency peak flows (100-year) for relatively low levels of urbanization. Estimates of neither high-frequency peak flows nor low-frequency peak flows are affected greatly by increases in the drainage improvements at relatively low levels of urbanization. Field reconnaissance in 2001 found the level of drainage improvements for the 
present Collyer Brook watershed is zero. The impervious area of the watershed more than doubled to 3.5 percent from 1964 to 1999 . Using these parameter values in the regression equations developed by Sauer and others (1983) yields a less than a 10-percent increase in the 100-year peak flow and a 21-percent increase in the higher frequency 2-year peak flow. Given the standard error of these equations (about 50 percent), it is plausible that the estimated 2-year and 100-year peak flows did not increase or that the change may not be detectable. High-frequency peak flows are sensitive to changes in impervious area at relatively low levels of urbanization, so future increases in impervious area may begin to have a discernable effect on peak flows. If drainage improvements were to increase in the basin as well, the effect presumably would become more pronounced.

\section{REFERENCES CITED}

Bedient, P.B., and Huber, W.C., 1988, Hydrology and floodplain analysis: New York, Addison-Wesley Publishing Co., 650 p.

Cowing, D.J. and McNelly, J.L., 1978, Drainage areas of surface water bodies of the Royal and Presumpscot River Basins in southwestern Maine: U.S. Geological Survey Open-File Report 78-556, 23 p.

Helsel, D.R., and Hirsch, R.M., 1992, Statistical methods in water resources: New York, Elsevier, 522 p.
Lee, J., Klosterman, R.E., Salling, M., and Kulikowski, T.D., 1999, Development of a community-accessible urban sprawl impact assessment system in northeast Ohio 15county region for the EMPACT project, Phase I report, Literature review for urban growth modeling and environmental impact analysis, Dept. of Geography, Kent State University, Draft: March 3, 1999, 83 p.

Maine Register, 2000 State yearbook and legislative manual, No. 131: Standish, Maine, Tower Publishing Company, $1161 \mathrm{p}$.

Neil, C.D., 1999, Significant sand and gravel aquifers of the Gray quadrangle, Maine: Maine Geological Survey, Open-File Map 99-24.

Nielsen, J.P., Stewart, G.J., and Caldwell, J.M., 2000, Water Resources Data-Maine-Water Year 1999: U.S. Geological Survey Water-Data Report ME-99-1, 193 p.

Sauer, V.B., Thomas, Jr., W.O., Stricker, V.A., and Wilson, K.V., 1983, Flood characteristics of urban watersheds in the United States: U.S. Geological Survey WaterSupply Paper 2207, 63 p.

U.S. Department of Agriculture, Natural Resources Conservation Service, 1995, Casco Bay watershed land use inventory, in support of the Casco Bay Estuary Project, 1st Ed., Gorham, Maine, Natural Resources Cons. Service, $75 \mathrm{p}$.

U.S. Department of Commerce, National Oceanic and Atmospheric Administration, 1992, Climatological data annual summary, New England: v. 104, No. 13. -, 1999, Climatological data annual summary, New England: v. 111, No. 13.

Weddle, T.K., 1997, Surficial geology of the Gray quadrangle, Maine: Maine Geological Survey, Open-File Map 97-58.

1999, Surficial materials of the Gray quadrangle, Maine: Maine Geological Survey, Open-File Map 99-61. 
District Chief

Maine District

U.S. Geological Survey

Water Resources Division

26 Ganneston Drive

Augusta, ME 04330 